\title{
Effects Of Sports And Social Well-Being On Physical And Mental Health Of Pakistani Women
}

\author{
Shagufta Jahangir \\ \& \\ Asma Manzoor \\ Women's Studies \\ University of Karachi
}

\begin{abstract}
Sports are very trendy observable fact in the world. It is the greatest extensive communal institution of contemporary civilization. It increases social hierarchies of any society, which is based on class, competition, gender and ethnicity. Almost all societies of the world aren't comfortable that women get involved in games, while it plays a vital role in shaping social, cultural and economic values. Usually Women at their peak lacks in physical and mental strength as compared to men because they cannot sustain fatigue and strain beyond certain limit therefore, they have to compromise their sports careers usually before attaining the highest goal. The objective of this study is to explore different perspectives regarding sports women in sports activities and it also aims to analyze critically the misconceptions regarding women sports. The researcher has used both qualitative and quantitative research method and by using snowball sampling technique collected data through the interview schedule from 210 sports women residing in different places of Pakistan and hence, five case studies are in corporated in this study. The findings of the study highlight that societal misconceptions have strictly prohibited women from sports activities because dominant people create misconceptions regarding women sports in the society according to their own perceptions. It is observed that wrong fallacies regarding sports activities are very strong in the Pakistani society, which restricts women to participate in sports activities. According to the research findings it is the responsibility of the Government to facilitate women and provide them different facilities which not only assure their mental health but also provide them opportunity of full participation in sports by providing them childcare facilities, economic stability, maintaining their social respect, self - esteem, and empowering them.
\end{abstract}

Keywords: Sports Women, Social Well-Being, Physical Health, Mental Health, Misconception.

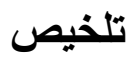

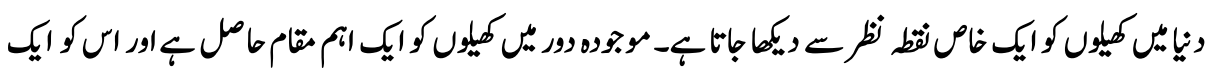

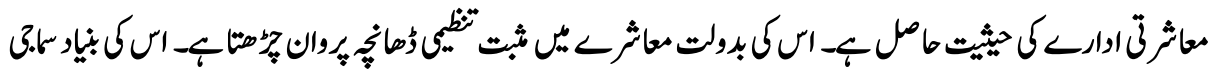




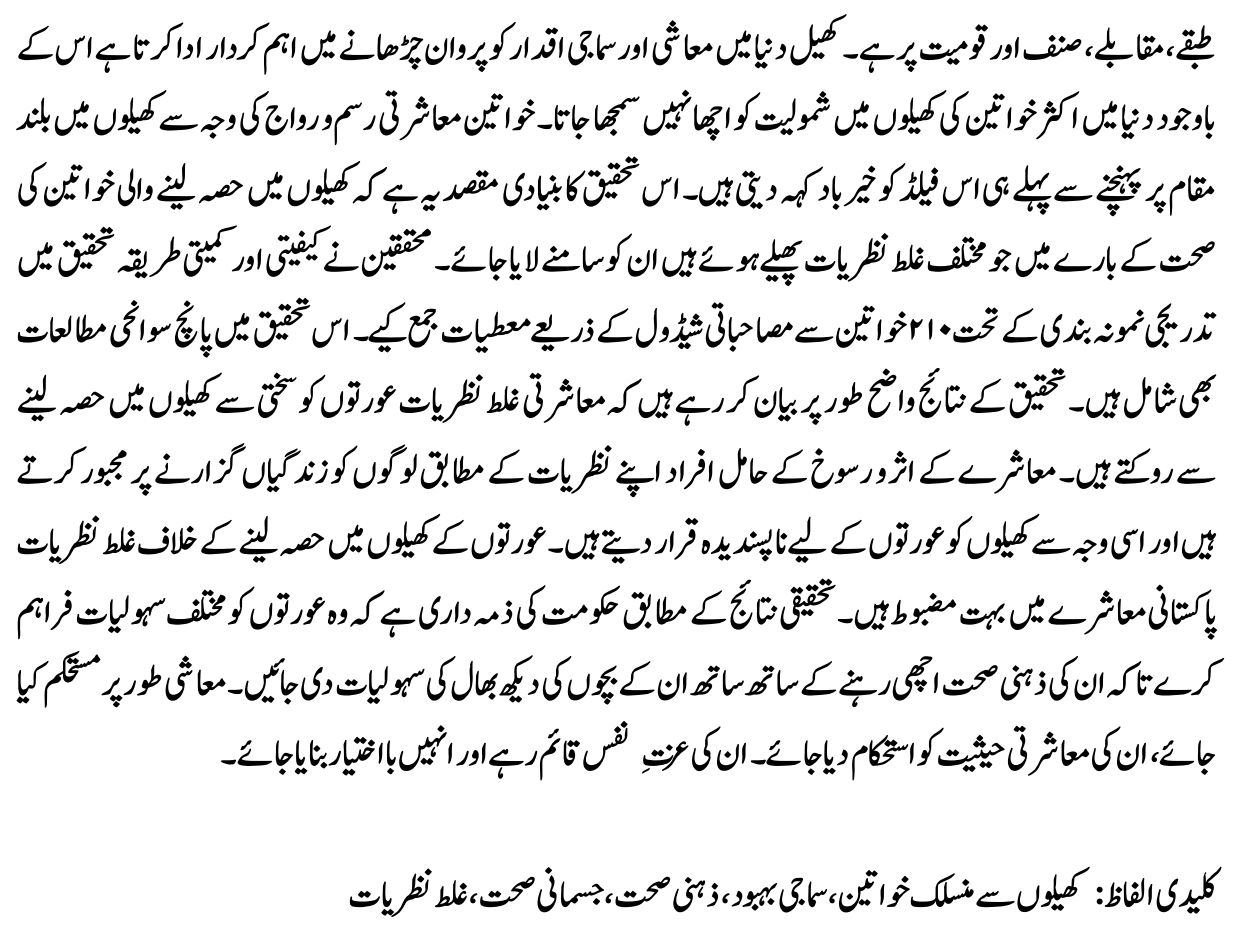

\section{Introduction}

During the last three decades many statements and declarations are present to show the sports values of sports, physical activities and physical education for women (Talbot 2010; Bailey, 1993). Sporting world is extremely beneficial for human development, health and fulfillment of their inner satisfaction (Hardman \& Stensel, 2003). Even Islam has encouraged women to participate in physical activities (Benn et al., 2011). Many researches of the United States, Australia and India show that sports women are much better than non - sports women in self-image, confidence, body image, outlook and socialization (James \& Stanly, 1991). Vigorous sports of women have notable development in current years in South Asian countries due to well - intended policies. In India individual sports like athletics, badminton, squash, tennis, swimming, boxing, scuba diving etc. have achieved more success rather than team sports like cricket, football, hockey, basketball, volleyball etc. (Fasting \& Knorre, 2005). Sports activities can help in abolishing the class, gender and cultural differences from the society (Sabo \& Vanfossen, 1989).

Self-dependency, improvising, naturalness, passiveness, submissiveness and subordination are the qualities of good sports women. Self-dependency gives confidence to players to control colleagues or coaches while through improvisation player clue to 
acting out of the rule - bound array of sports. Naturalness represents the private worth of players like the individuality of player, tactics, skills, equipment and techniques. Through passivity player want to curb training activities to pledge exact training schedule. Through subordination player receives the positive criticism and adjust their previous habits and tactics. Through submissiveness player follows the instructions, rules, parameters, regulations and conventions of the game and to learn the spirit of winning or losing the game. Sports provide an opportunity to women to reevaluate myths, norms and customs for themselves and it also empowers them in the society (Oglesby, 1981). The subordinate groups of the society do not accept socially dominated gender norms while; sports provide a channel for women to confront socially constructed values, myths, norms and feminine gender roles (Sage, 1998), though it seems that sports offer liberation to women (Newhall et al., 2008). It even provides the opportunity to women to communicate and interact in groups that are heterogeneous in terms of age, sex and ethnicity (Sabra et al., 2010).

Women participation in sports activities created not only the practical skills in women but also enhances self-esteem, self - confidence; develop strength and physical skill of women through their sports capabilities. Sports also give fortification against sexual abuse to women (Sabo et al., 1989). Sports not only increase the educational score of sports women (Miller et al., 1989), but also increased college attendance, (Development Bank, 2000) on the other hand decreased the level of women's health issues (Omer Malik, 2014). Sports increase education level, mental health, physical health, communication skills, negotiation skills, leadership skills, sense of ownership over their bodies, improving public health \& well-being, self-esteem and better understanding to provide them choices about their own lives. A sports activity socializes women and create friendly environment between men and women (Benn et al., 2011).

Women after gaining confidence by developing their skills through sports are participating now even in those sectors of sports where they were restricted to enter earlier. They have shown great deal of strength by proving their worth that they have the ability to compete men in all fields of sports whether physical activities, managerial skills or administrative positions. After earning all these skills and status they grow further in skills and abilities, which provides them calmness, tranquility, pleasure and liberty of expression (Hargreaves, 1994). Australian Sports Commission describes that there are lots of hurdles which are practically discouraging women to participate in sports, like less sports amenities, shortage of skills, shortage of abilities and resources, shortage of technological resources, physical constraints, shortage of time, shortage of childcare facilities, physical/verbal sexual harassment, playing areas, playing time, shortage of 
female role models, unavailability of female coaches, lack of decision making power, sports attire, traditional problems, household tasks, family expectations and the societal environment of sports organizations (Kirchmeyer, 1998).

It has been observed that through high social support is one among important key factors to boost up the performance of anyone, even social optimistic approach effects on physical, mental and psychological health (Benn et al., 2011). Sports management and social scientists think that the low participation of women in sports is a socio-economic dilemma (Cunningham \& Sagas, 2008). Positive societal encouragement provokes for better performance and achievements in all fields of life (Cohen \& Syme, 1985).

\section{Literature Review}

Scholarly research literature described that sports women are better than average women in every walk of life because they have maintained their persona and they have managed to prove their worth in the existing social structure by associating themselves as confident and mature women. According to this literature, sports women do not have any fear of competing with males. Sports women attuned with the sports world without losing their expressive abilities and contributory abilities to achieve high stature in sports. It means women are getting benefits from sports and they should be manipulating sports in an optimistic manner. Literature also suggested that women avoid the values of customarily managed subjugated sports. Iconic and successful sports women are able to fight against the false myths, norms, traditions and customary practices of the society (Butt, 1987).

History also shows women as inferior, dependable and powerless than men. Social, economic, political and socio-religious values strictly prohibit women to enter in sports. It is very difficult for women to play as sports women due to socially constructed values. It is really a great accomplishment for women to achieve so much, which they have so far. Besides all these problems, gyms, fitness centers, training centers and coaching institutions provide training to dedicated sports women to participate in sports professionally. Schools are also providing young girls to take part in several athletic feats in the society. These all petite efforts gradually increase the participation level of women's in the sports activities. Similarly, sociologists find out that sport personally empowered women (Young \& White, 1995) while, on the other hand social life of women is very weak, powerless and dependable (Blinder et al., 1994). Even media used women body as an object to be looked, evaluate and consumed, while sports give the power to women to control on their bodies and overcome the feelings of their bodies are an object. Furthermore, strong physical skills are earns by sports activities which can 
make her feel less vulnerable, confident, control on her physical safety, independent, and psychological well-being (Young \& White; 1995). According to the (President's Council on Physical Fitness and Sports Issues, 1997) on women and girls lives that coaches, sports persons, parents and society supposed that sports activities have countless benefits in the women lives. This report proves that women get physical (less obesity, osteoporosis, heart disease and vulnerable diseases), academic (better performance, higher test scores, lower risk of leaving education), psychological (less depression, higher self-image, good body image, increase sense of competence) benefits.

Sports prevent human beings from vulnerable diseases. Women's they have been capable to do more aerobic to keep fit than others (Nelson, 1998). Steady isometrics declines the rate of depression (Faulkner \& Taylor, 2005) in women (Page \& Tucker, 1994). Swimming; weightlifting and body building diminish down the heart diseases in women (Ahmadi, 2002). The ratio of suicide is extremely very lower in athlete women rather than non - athlete women (Sabo, 1989). Sports women are more confident, self - concept brave and regularly at school. Sports girls are sincere to her education (Marsh, 1993). Homework punctuality is present in her. Women are more intelligent in Science and Math (Marsh, 1993).

Sports reduce the risk of breast and colon cancer in women (Willett, 2003). 37\% breast cancer risk is declined by sports in women (Thune, 1997). Sports women have very low risk of osteoporosis. Athlete women have 1\% risk of bone density while non - athletic women have $2 \%$ risk of bone density (Bonaiuti, 2002). Weekly one to three hours exercise reduce the risk of breast cancer while more than four hours weekly exercises decline the risk approximately $60 \%$ (Bonaiuti, 1994). Sports women start sexual activity letter and sports also prevent them about sexual risks (Sabo, 1996). Scientific researches show sports increase cognitive memory skills, academic achievements and mental health (Anjan, 2015). Western sports women are fitter, stronger, faster, skillful, and better rather Muslim women because they apply scientific methods to improve her while, Pakistani sports women pretentious by her social myths and norms. She forever overwhelmed by the male dominated culture and almost come forward to assert that coaches, selectors, lower staff demand sexual favor (Hargreaves, 2007). 
Source: by Author.

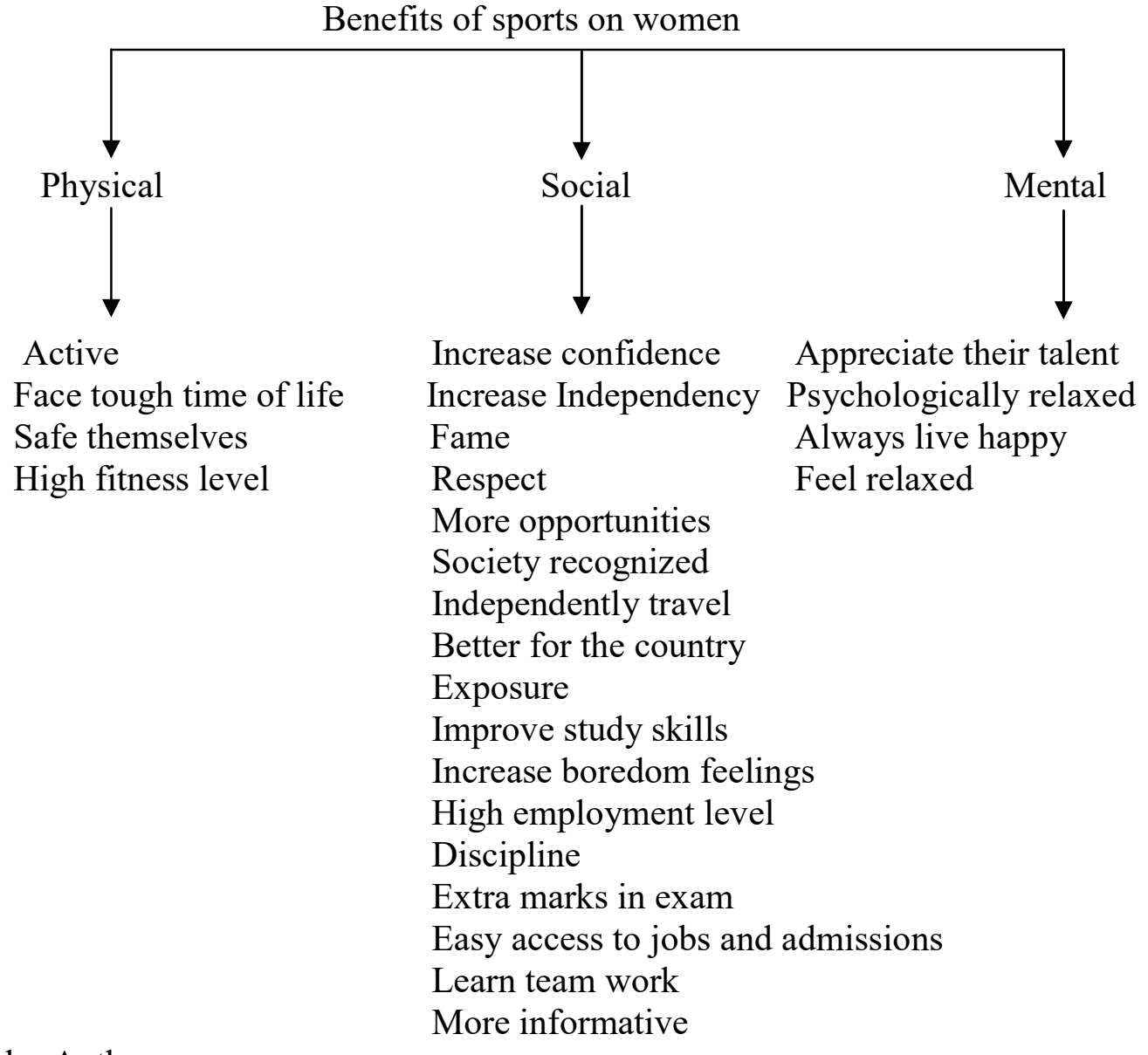

Sports reduce the risk of breast and colon cancer in women (Willett, 2003) according to their available statistics $37 \%$ breast cancer risk is declined by sports in women (Thune, 1997). Sports women have very low risk of osteoporosis. Athlete women have 1\% risk of bone density while non - athletic women have $2 \%$ risk of bone density (Bonaiuti, 2002). Similarly the main reason of morbidity, mortality and poor health of women is the lack of sports and physical activities in Pakistan, Bangladesh and almost all South Asian countries (Sriskantharajah \& Kai, 2007). Weekly one to three hours exercise reduces the risk of breast cancer while more than four hours weekly exercises decline the risk approximately $60 \%$ among women players (Bernstein, 1994). Sports women start sexual activity letter and sports also prevent them about sexual risks (Sabo, 1996). Scientific researches show sports increase cognitive memory skills, academic achievements and mental health (Anjan, 2015). Western sports women are fitter, stronger, faster, skillful, and better rather Muslim women because they apply scientific methods to improve her while, Pakistani sports women pretentious by her social myths and norms. She forever 
overwhelmed by the male dominated culture and almost come forward to assert that coaches, selectors, lower staff demand sexual favor (Hargreaves, 2007). Skilled sports women can easily changed the way of her. Sports women is physically stronger competent and individually independent. Sports also provide an opportunity to women to reconnect with the ability of their bodies. The value of sports for women is incontrovertible.

Duncun et al., (2004) and Hardman \& Stensel (2003) illustrated that sport have several positive impacts on human's lives specifically towards health benefits, it is also observed that it helps in reducing excessive weight loss, reduce diabetic level, and prevent cardiovascular diseases. It is believed that playing sports regularly will have long term effects on good health and also provides quality life to the masses. Basically, such activities stretched and contracted bodily muscles which produce energy inhuman body. However, it is also said that not only particular sports but including other physical works such as work, exercise, prayers, workout as well as various athletes and gymnastics played essential role in well-being of human healthy environment (Astrand et al., 2003).

According to previous available researches regular sports can work against antidepression and reduces various symptoms of diseases including of mental health and anxiety. Because it is mentioned in the readings of (Faulkner \& Taylor, 2005) study that people who are playing sports on regular basis have lower depression score as compared to people who do not play regularly. However, depression can lead to many other dysfunctions including weight loss, lower self-esteem, frailty, mental distress, cognitive impairment, and so on. Whereas; sports should be a part of life it would yield strong bodily functions and help masses to control depression in such era of inflation and recessions. In such scenarios every single person is hampering with such economic downturns, so through sports we can spend some time for entertainment purpose and would have happy and enjoyment with friends, family and peer groups. Hardman \& Stensel (2003) highlighted that in western countries most of women are suffering from obesity, it is attributed with the use of technology, as researcher believed that physical activities have reduced work done by women as it impacted on women's health as their weight increases. However; in ageing women (especially obsessed) duration of menopause could lead to negative consequences which include loss of bones. In such scenario, there must be proper exercise programs in order to avoid pre and post menopausal affects on women.

Leila et al., (2015) pointed out that in Iran and Arab countries women cannot participated in sports activities due to their domestic responsibilities and more than that socially constructed values contribute in this regard. Similarly in Pakistan women are restricted from sports activities due to socially constructed values, WHO statistics show that only $27.3 \%$ women take part in sports activities (World Health Organization, 2008). On the 
other hand it is a fact that through sports women can gain enormous benefits. Jamshed \& Ahmed (2010) suggested that it is highly needed to recognize and promote women sports so that Pakistani women can gain benefits socially, culturally and economically as well. Pakistani women should be empowered so that they can raise voice and can participate in decision making at an individual level in order to gain access in policy making, resource management and allocation along with taking part in development planning and programs. To increase women's participation in sporting activities at all levels their role should be more specialized and identified in all sporting domains, so that they can gain access to all available opportunities and support mechanism. By following such mechanism only role of women in sports can be made more productive and effective. In such circumstances, this study topic has been chosen to recognize the benefits of females in sports and highlighting their existence in their social lives.

\section{Methodology}

The research on the effect of sport and social well-being on physical and mental health of Pakistani women had never been discussed or explored before in the country. Due to the reason, it became the prime topic of interest for the researcher to analyze the well-being of sports on the women. The participants were interviewed by the researcher by using snowball sampling technique of no-probability sampling method; these respondents are the sports women who are engaged in different sports. It was very difficult for researcher to contact different sports women. For this task researcher searched the contact list of captains, organizers and secretaries of different federations, collected and subsequently contacted via the phone, take the time, then meet the association's members, show permission letter of the Centre of Excellence for Women's Studies, University of Karachi, Karachi, Pakistan and finally connect to sports women.

Firstly, researcher explained the purpose, then explained about the study verbally and distributed the questionnaire. Numbers of questionnaires distributed was depending on the willingness of full agreement of sports women. Some sports women were not physically in researcher access, so researcher took her interviews via telephone. The researcher collect data through interview schedule from 210 sports women residing in different places of Pakistan with review of global literature. They are all in the age bracket of between 11 to 41 years. All of the participants belong to different individual and team sports. Almost all the interviews conducted at respondents practice place, home, universities, federations, clubs or cafeteria. Approximately 109 interviews were conducted through direct communication. 41, were done after sending letters to the different sports federations while 23 , were conducted by telephonic communication. 19 , questionnaires are filled through the federations and were sent back to the researcher via mailing address like mountain climber. 18 interviews were done through other sources (personal relations). An interview completed approximately 40 to 50 minutes. The 
women have been engaged in cricket $(n=35)$, hockey $(n=27)$, football $(n=23)$, martial art $(n=15)$, table tennis $(n=10)$, badminton $(n=13)$, squash $(n=03)$, chess $(n=05)$, athletes $(n=29)$, Swimmer $(n=26)$, Tennis $(n=05)$, Golf $(n=02)$, Mountain climber $(n=02)$, Power lifter $(n=03)$, Scuba diving $(n=02)$ and Boxing $(n=10)$. The participants are playing in national and international competitions and Olympics. Some participants are the iconic and explore the name of Pakistan internationally. Minichiello et al., (1997) argue that through semi-structured interview researcher observed the daily routine of a respondent.

\section{Demographic profile of respondents}

\begin{tabular}{|c|c|}
\hline Ethnicity & $\begin{array}{l}\text { Sindhi (6.6\%), Punjabi (30\%), Balochi (16.6\%), Pathan } \\
(26.6 \%) \text {, Mahajir }(20 \%)\end{array}$ \\
\hline Religion & Islam (84.28), Christian (4.2), Hindu (2.38), Ismaili (9\%) \\
\hline Age & $11-41$ \\
\hline Gender & Females $(100 \%)$ \\
\hline Playing Professionally & Yes $(31 \%)$, No $(69 \%)$ \\
\hline Qualification & $\begin{array}{l}\text { Secondary school certificate }(7.1 \%) \text {, O level }(5.2 \%) \text {, Inter } \\
(30 \%) \text {, A level }(3.3 \%) \text {, Graduate }(40.9 \%) \text {, Master }(8 \%) \text {, } \\
\text { Diploma (DAE) }(5.2 \%)\end{array}$ \\
\hline Marit: & Married $(18 \%)$, unmarried $(81.9 \%)$ \\
\hline Type of family & Joint family $(68 \%)$, Nuclear family $(31.9 \%)$ \\
\hline
\end{tabular}

Source: Author's own data

\section{Case Studies}

\section{Sana Mir (Cricketer)}

Sana Mir is the daughter of (R) Colonel Mir Moatazid. She began to play cricket on the streets. She has been travelling all around Pakistan due to postings of her father. She always desired to join the army to serve the nation just as her father did. She especially mentioned Taxila Cantt and Gujranwala Cantt in this regard where she used to call children from her locality to play cricket in the street she loved to play the whole day. When she started to plat, at that time there were no proper cricket facilities for females at schools, colleges, universities level or at any other place. So there was hardly any female cricket club during 90s, therefore, she learnt cricket in galis / Mohall's (streets) and reached this current status where she is today. Her primary schooling was in Rawalpindi. Then they moved to Gujranwala and after passing her $6^{\text {th }}$ grade they moved to Taxila where she completed her Matric. From Taxila after they shifted to Karachi where she accomplished her Inter and Bachelor's degree before settling in Lahore, where she has settled at present. Her education and cricket have been going side by side and she strained 
to accomplish both things simultaneously. After that, she took admission at the National University of Science and Technology (NUST) as an engineering student. It was the hardest time for her to choose between cricket and engineering. At that time her father assisted her and gave her a piece of advice in the words" Pakistan has many female engineers, but no female cricketer so you should go and make your fantasy comes true. Her father's assistance turned her life and she became a cricketer.

She gives all credit to her family, especially to her father, without his support, she might not have been able to do so, what she is today. Her father always encouraged her to play outdoor sports and never discriminated between a boy and a girl among his children. She also mentioned about her mother who always helped her in difficult times and facilitated her in every possible way. Her brother was her first coach who used to take her to the ground and skillfully helped her in learning the game. Even her sister and brother-in-law have encouraged her at every step. She can confidently claim that her entire family is at her back. Moreover, the result is in front of us, that she is the captain of the Pakistan Cricket team. She is very shy in nature but due to involvement in sports activities she socialized and understands the way of life as well as feels physically strong and mentally calm.

\section{Naseem Hameed (Athlete)}

Naseem Hameed was born on $1^{\text {st }}$ May 1988, in Karachi. She lives in Karachi with her parents and two siblings. She is very thankful to her mother for her success. She was involved in sports since her childhood and participated in every sports event in school and college activities. She had won many medals and trophies during school and college period. Her school management sent a letter to get permission from her parents for registering her in school sports activities, but as her parents restricted her, therefore she signed the letter by herself and gave back to her school teacher. After that she achieved huge success and won medals and trophies. Mr. Muhammad Talib was her first coach from whom she learned many technical points. She also used to practice in Army grounds, during college days. After that she got engaged with Pakistan Railways. She has earned 300 medals, 12 shields and 150 trophies during her entire career.

She represents Pakistan in SAF Games 2010 at Dhaka (Bangladesh) and won 100 meters, 11:81 clocks and was entitled as "Fastest Women in South Asia". She received trophy and 30,500 U.S dollars, approximately 2.6 million PKR. President of Pakistan made her ambassador of sports, while the governor of Sind assured her for a plot as a property in terms of reward. She is the fan of Pakistani legendry singer Nusrat Fateh Ali Khan Sahab

and is also very fond of watching films and wrestling. Naseem is also a huge fan of Bruce Lee and is greatly inspired by Shabana Akhter (athlete). 
She lives in a slum area of Korangi (Karachi). She belongs to a poor family. According to her it is quite common in her residential area that females / women are supposed to spend their lives inside the four walls fulfilling their domestic responsibilities. It is not appropriate for women to spend time outside the home. She is very thankful to God that her achievements have broken this social taboo. Her success has opened the doors for the sports loving women to enter in sports with braveness and confidence. Participation in sports activities provides her physical fitness, mental relaxation and social benefits.

\section{Nida Waseem (Tennis)}

Nida Waseem was born on November 1, 1982 in Karachi. She started playing tennis at the age of seven years and became the first Pakistan's woman tennis champion in the age of fourteen. Initially she did not take it seriously and started to play tennis as an activity. Her favorite player in her childhood was Andre Agassi and now Roger Federer is her inspiration. Nida is very fond of playing since her childhood. Her parents encouraged and supported her in every walk of life. Nida took playing and studying equally important simultaneously though it was tough. She is much disciplined and manages her time and routine perfectly. Her school principal also supported her for playing. Currently she is studying Law in London. Nida participates in Australian Open, French Open and Junior Wimbledon Championships. She is ranked $108^{\text {th }}$ in single and $87^{\text {th }}$ in double in 2000 as a world junior ranking system. In 2000, she won titles along with the under 10 players of the world. She plays in New Zealand, Japan, America and Thailand and has won highest number of cups among her age group female players. Her luminous and remarkable achievement in the international circuit entitled her for scholarship at Boston College (America). She is the Caption of tennis team in her college. In 2007, in $30^{\text {th }}$ National Games, she defeated three gold medalist of her college. This remarkable performance shows her brilliance.

In 2008, government of Pakistan gave her pride of performance award in the governor house. She was the only female player amongst the $29^{\text {th }}$ Sind domiciled people, who received the prestigious awards from the Governor of Sind Dr. Ishratul Ibad Khan in recognition of her outstanding performance in the last decade both at national and international level. She was also awarded a cheque of Rs 0.3 million. She has won 7 times Women tennis champion for Pakistan. She has represented Pakistan in several countries for playing tennis. She thinks that she could have achieved more, but lots of things were involved at that time, which kept her away from participating in more events. She thinks that she has the potential to achieve more, but the limitations and restrictions in sports in our country kept her away from participating in all events at national and international level. According to her she could have left sports field if her family was not so supportive. She thinks that lack of support, poor infrastructure, lack of sincerity, low social activity of youth, and lack of basic knowledge has become the reason of decline 
and popularity in sports, while tennis requires exposure, finance, planning, equipments, courts and lots of grooming. Through sports participation she is capable to handle the issues and problems of life, get fame, money and respect in the society as well as physically powerful and mentally stress-free.

\section{Twinkle Sohail (Power Lifter)}

Twinkle Sohail is a gold medalist. She earned gold medal in Power lifting Championship at Muscat (Oman) in 2015. The Pakistani female power lifters collected twelve points (56.01 w. pts) in this event. The Pakistani women team comprises of Twinkle Sohail (57kg), Sonia Azmat (63kg) and Shazia Knawel Butt $(84 \mathrm{~kg}+)$, Twinkle Sohail has brightened the name of Pakistan by scoring gold medal in her category.

She surfaces as Pakistan's first female weight lifter to have won a Gold medal in an International event. She is only nineteen years old, gold medalist who hails from Pakistan (Lahore), out classed athletes from 12 other countries at Sultan Qaboos Stadium in Oman (Muscat). She was extremely happy, excited and proud, she exclaimed. She maintains her joy is immeasurable, as toiling, in the gym for last two years as paid her off and is extremely thankful to God for blessing her with such great parents and family members who have played a vital role in her accomplishments.

She competed in the $47 \mathrm{~kg}$ junior less than 21 event and was declared triumphant after six white flags hoisted from the judges seeing that she outdid her competitors in all three lifts flawlessly. She was little nervous before coming here and competing at the top level in the continent. She kept her nerves in check and she had to perform well. She maintained her focus and was a winner in her category. She said, that she could sense victory in the third round and was so sure that she had grabbed win for Pakistan.

She is glad as a female weight lifter, she won first gold medal for her country. She had never thought of this achievement as previously she was a cyclist and wanted to make a name for herself as a cyclist, but God had another plan for her. She was extremely careful in her performance very calculated and managed to lift weight beyond her capacity. She still cannot believe that she had become the first female Pakistani power lifter to win something this big. She is still processing the feat. She said while still being gob smacked at her victory. She is a very soft spoken girl and rolling with full force in sports in every corner of the world.

\section{Kulsoom Hazary (Karate)}

Kulsoom Hazary lives in Karachi, Pakistan. She has been playing Karate since her childhood. She has participated in many national and international events and has won 
several medals for Pakistan. Apart from Karate she is doing her graduation from Karachi University. She has participated several times in national and South Asian championships. She plays for WAPDA; a well-known department who has a good record of winning national championships in several sports. She is very enthusiastic, passionate and determinant about participating and winning Gold medal in Olympics. Despite of inadequate facilities and resources she is a very optimistic about her future and vows of winning more medals for Pakistan.

She has been the national karate champion for three years and her love for the sports comes from somewhere deep down. Her late brother-in-law introduced her to the sports in 2000, in order to flush out her anger and pain. Her mother passed away when she was eight and her father died five years later. She had to make something out of her life and karate was all she was left with. She internationally Participated in $4^{\text {th }}$ women Islamic Games in Iran and secured $5^{\text {th }}$ position (2005), 2006 (Colombo, Sri Lanka), 2010 (Dhaka, Bangladesh) and 2011 (New Delhi, India). South Asian games and has won 6 Medals (2 Gold +4 Bronze). She is the South Asian Gold Medalist. She again won three Gold Medals in 32th National Game which had commenced from 22 to 28 Dec 2012 in Lahore Pakistan. Nationally she has a record of winning 3 time's National Women Karate championship award and two times' National Games Karate Championship.

Last year She won the 60 - kg Gold a South Asian event in India and as she prepares for what lies awaiting in Tashkent, she reminisces about the rocky road to success. She is from Quetta and her relatives as well as the community have never been supportive of her passion. She comes from a conservative society but the support she got from her sister, her husband laid a strong foundation, and it was their encouragement that drove her into this.

She belongs to the Hazara community but she carry on with this, knowing fully that our culture dictates. Her community is conservative. She is doing Masters of Arts (MA) in Health and Physical education and envisages herself as a fitness consultant and coach while helping future female karate players. Since a decade, Pakistan Karate Federation (PKF) sends women players to the Asian Championship so that says a lot about how women are being ignored in the sports.

\section{Results and Discussion}

Social well-being on physical and mental health is the vast topic in the world. Research clearly shows that a sports woman is energetic, mentally strong, disciplined, tougher, healthier, proud, active, confident, risk taker, balanced, developed personalities and bold. It means that sports developed women by all means. Furthermore researcher also point out that family and society give more faith to sports women then other women. Sports 
women are the symbol of honor for the country, people impressed by them, people admire them, people supposed that sports women are different to other women.

This is the common myth in almost Asian countries that sports decline the ability of women's reproduction capacity and it is harmful during menstruation cycle but study shows that consequences are too differ because $63 \%$ sports women said that they have no issues in menstruation during sports activities even it have positive effects on the sports and only 3\% sports women said that they take medicines. Some of them about $5 \%$ said that they avoid playing specifically two days. Out of the whole sample about $11 \%$ told that reduce the time span of practice, moreover $18 \%$ said that they skip practice. Every sports woman said that there periods are exactly regular and accurate. It means that sports activities do not harmful effects on the women health. These comments show that the wrong myth about sports activities gradually changed in the society. The overall sports women said that people supposed that female players have ideal personality and appreciate us very much. Society has encouraged us for the top position. Almost whole respondents said that sports activities are very helpful for us because it activates our minds and we pick up Math and science subjects quickly.

Among all human activities sports is among one of the most healthy and essential activity to improve their health and to have physical and mental relaxation. Pakistani women already know the importance and value of sports activities for their physical, social and mental health and they have an utter desire to participate in sports activities for their complete potential growth (Khan et al., 2012). It not only increases physical and mental health, but also gives social benefits to women; it also provides opportunities to women to participate in social and cultural activities of their communities and promote enjoyment, freedom of expression and new opportunities for themselves. Sports activities increase the mental health of women of all ages and it even improves and refreshes women from unhealthy activities of life by providing them leisure time. Sports can improve women's self-esteem level and can boost up their confidence level through social integration.

Sports basically redesigns our lives and personality, therefore, by promoting women's sports we can strengthen women's hidden talents before the world to show their true strength to compete men. Physical activities can enhance women's well-being by developing leadership qualities in them and can also help in improving civic sense, so that women can consider themselves socially and culturally beneficial like men. Hence women sports should be promoted to convert women into productive part of the society, thus giving them a chance of becoming self-administered agents of social change.

When we compare the fitness level of Pakistani women players with International players it shows that fitness level of our women players is low. According to data $21.428 \%$ 
respondents said that their eating habits are not healthy, they like junk foods, love to eat chocolates, like to take soft drinks instead of milk and fresh juices and do not like to take fruits and healthy foods, while $20.476 \%$ respondents said that social constraints restricts them to do daily physical activities to make them fit because they are not allowed to go alone for net practice and health clubs for regular exercises. Any sport activity requires daily practice and routine exercise which is necessary for their fitness and endurance but unavailability of separate women health clubs and separate practicing grounds make them dependent on their male family members to take them along for their daily routine practice which is almost impossible to do it on regular basis, 20\% respondents reported that their hectic life style was one of the main reasons of their low fitness level because they are triple burdened, they have to look after their family, have to do daily house hold chores along with their daily routine physical exercises which won't allow them to take plenty of sleep to make them fresh and active for sport activities, whereas $18.571 \%$ said that due to unstable economic position their fitness level is very low as compared to other international players because they cannot afford to take high nutrient value food which is necessary for their physical fitness and muscular endurance, $16.666 \%$ said that domestic responsibilities including reproductive and productive work like child rearing and bearing, taking care of elderly family members, alternate income generation to earn their bread and butter to support their family also over burdened them and increase their stress level and affects their fitness, while $2.857 \%$ said that weight consciences also play a vital role in the low level of fitness because a myth prevailing in the society that a thin and lean body women looks more beautiful than a bulky women.

Figure 1: Distribution of respondents according to why Pakistani sports women health and fitness level is low as compared to other international sports women

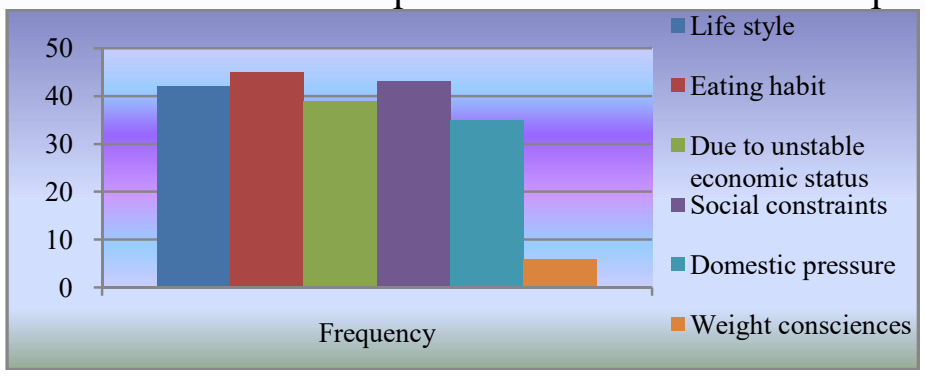

Pakistan Association of Women Sports (PAWS) managed seminars, workshops and clinics to enhance, aware and support sports women due to huge benefits of sports activities. Sports empowered and develop personality building along with controlling health issues and last but not the least will bring economic stability of Pakistani women. Pakistani government need to revise their policies regarding women's sports, because some individual sports need immediate action for their stability. (Jahangir, 2018). 


\section{Conclusions}

Pakistani sports women are facing many social problems than others sports women in the world. Besides all the restrictions and lack of facilities to Pakistani sports women, it is found that they are extremely very talented, powerful, strong, healthy (physically, mentally \& socially) and courageous. Sport is a healthy activity which provides grounds for ideological thinking and for developing better gender relations. Research findings clearly describe that it is very important to aware the society about the health benefits of the sport activities and its importance in developing nations especially in a way to lead healthy life. Researcher's observation and result of the study clearly indicated that effect of sport have positive impacts on social well-being of women especially in physical and mental health.

Still we need to aware masses especially women and children about the importance of sports in daily routine. But it needs efforts of Pakistani government, non-governmental organizations, media, society, and sports federations for widespread of physical activities through sports. It is the responsibility of the society to encourage the self-motivation in women/girls to scrutinize their thoughts at all levels besides preventing them from participating in sports. For the last two decades, the opportunities for sports women have increased and the society's attitude has been changing for sports women. It is positive outcome but still there is a long way to go (for women) to set landmarks in sports. More researches have to be done in future on the status of sports women which may bring further insight about the sport activity and the significance of women in sports.

\section{Recommendations}

- There must be a separate subject for sports at educational levels; where teachers can explain the benefits of sports for the physical and mental health for girls.

- There must be specific spaces or infrastructures for women where they can have various curricular and extra-curricular activities for their physical development.

- State should encourage and give incentives/benefits to girls and women to take part in sports activities.

\section{References}

Ahmadi, J., Samavatt, F., Sayyad, M. \& Ghanizadeh, A. (2002). Various Types of Exercise and Scores on the Beck Depression Inventory. Psychological Reports, vol.90:3, pp.821-822. 
Ahmed, Jamshaid \& Ansari, Muhammad, Akram (2010). Gender Differences of SelfConfidence in Sports with Reference to Pakistan Socio-Cultural Factors and Attitudes towards Women, www.sujo.usindh.edu.pk/index.php/THE-SHIELD/ article/view/1007/945

Anjan, B. J. (2015). Sports Physical Fitness Activity and its Educational Impact. International Journal of Academic Research, vol.2:4, pp.2348-7666.

Astrand, P., Rodalh, K., Dahl, H.A. \& Strome, S.B. (2003). Textbook of Work Phsiology: Physiological Bases of Exercise ( $3^{\text {rd }}$ edition).Champaign, Human Kinetics.

Bailey, N. (1993). Women's Sport and the Feminist Movement Building Bridges, Sage Publication, 297-304.

Benn, T., Pfister, G. \& Jawad H. (2011). Muslim Women and Islam, International Studies in Physical Education and Youth Sports, pp.265-264.

Bernstein, L., Henderson, B., Hanisch, R., Sullivan-Halley, J. \& Ross, R. (1994). Physical Exercise and Reduced Risk of Breast Cancer in Young Women. Journal of the National Cancer Institute, vol. 86, pp.1403-1408.

Blinde, E.M. \& McCallister, S.G. (1994). Women, Disability and Sport and Physical Fitness Activity: The Intersection of Gender and Disability Dynamics. Research Quarterly for Exercise and Sport, vol.70, pp.303-312.

Bonaiuti, D., Shea, et al., (2002). Exercise for Preventing and Treating Osteoporosis in Postmenopausal Women (Cochrane Review), Oxford Publication, p. (n).

Butt, Dorcas Susan, (1987). The Psychology of Sport: The Behavior, Motivation, Personality and Performance of Athletes. New York, NY, US.

Cohen, S. \& Syme, S. (1985). Issues in the Study and Application of Social Support. In S. Cohen \& S. Syme (Eds.), Social Support and Health New York: Academic Press, pp.3-22.

Cunningham, G. B. \& Sagas, M. (2008). Gender and Sex Diversity in Sport Organizations: Introduction to a Special Issue. Sex Roles, vol.58, pp.3-9.

Asian Development Bank (2000). Country Briefing Paper. Women in Pakistan. Programs Department (West) and Office of Environment and Social Development. Asian Development Bank Publication. 
Duncan, J.M., Al-Nakeeb, Y., Nevill, A. \& Jones, M.V. (2004). Body Image and Physical Activity in British Secondary School Children. Eroupean Physical Education Review, vol.10:3, pp.243-260.

Fasting, K. (2011). Sexual Harassment in Sports toward Female in three European Countries, International Review for the Sociology of Sport, vol.46:1, pp.76-89.

Faulkner, G.E. \& Taylor, A. (2005). Exercise, Health and Mental health: Emerging relationship, London, Routledge.

Hardman, E. A, Stensel, D.(2003). Physical Activity and Health: The Evidence Explained. London, Routledge.

Hargreaves, J. (1994). Sporting Females: Critical Issues in the History and Sociology of Women's Sports. London: Routledge

Hargreaves, J. \& Vertinsky, P. (2007). Routledge Critical Studies in Sport. Physical Culture, Power and the Body, London \& New York: Routledge/, p.98.

James H, Stanly, D. (1991). Sports and Society. Annual Review of Sociology, vol.17: pp.503-522.

Jahangir, Shagufta (2018). An Analytical Study of Social Problems of Women Related to Sports, PhD Thesis, Unpublished Thesis, Centre of Excellence for Women Studies, University of Karachi, Pakistan, p.6.

Kirchmeyer, C. (1998). Determinants of Managerial Career Success: Evidence and Explanation of Male/Female Differences. Journal of Management, vol.24: pp.673-692.

Khan, M. Y., Jamil, A., Khan, U. A., Kareem, U. \& Imran, G. (2012). Female Students' Opinion about Women's Participation in Sports. International Journal of Academic Research in Business and Social Sciences, vol.2:9, pp.275-283.

Lawton J, Ahmad N, Hanna L, Douglas M. \& Hallowell, N. (2006). I Can't Do Any Serious Exercise': Barriers to Physical Activity amongst People of Pakistani and Indian Origin with Type 2 Diabetes, Us National Library of Medicine, National Institution of Health. 
Leila AF, Mohsen AL, Eesa M, Soroor P, Ali AH, et al. (2015) Community-Based Physical Activity Interventions among Women: A Systematic Review. Retrieved from: https://bmjopen.bmj.com/ on February $8^{\text {th }} 2019$.

Marsh, H.W. (1993). The Effects of Participation in Sport during the Last Two Years of High School. Sociology of Sport Journal, vol.10, pp.18-43.

Miller, K. E., Sabo, D., Melnick, M. J., Farrell, M. P. \& Barnes, G. M. (2001). The Women's Sports Foundation report: Health risks and the teen athlete. East Meadow, NY: The Women's Sports Foundation

Nelson, N.E. (1998). Strong Women Stay Young. New York: Bantam Books

Newhall, E. Kristine \& Buzuvis, E. Erin, (2008). Sexuality and Race, Law and Discourse in Harris v. Portland. Sage Publications.

Oglesby, C.A. (1981). Myths and Realities of Black Women in Sport. In T. S. Green, C. A. Oglesby, A. Alexander, \& N. Frank (Eds.), Black Women in Sport (pp.113).Reston, VA: American Alliance for Health, Physical Education Recreation and Dance.

Omer, Malik, Tazeen Saeed Ali \& Noureen, Karamali (2014). Women's Perception and Attitude towards Male Dominancy and Controlling Behavior, Arts and Social; Science Journal, Aga Khan University, Karachi, Pakistan, pp.5.

Page, R. M. \& Tucker, R. A. (1994). Psychosocial Discomfort and Exercise Frequency: An Epidemiological Study of Adolescents. Adolescence, 29(113):183-191.

Sabo, D., Melnick, M. J. \& Vanfossen, B. (1989). The Women's Sports Foundation Report: Minorities in Sports. New York: Women's Sports Foundation.

Sabra L.Katz-Wise, Heather A. Priess \& Janet S. Hyde. (2010). Gender-Role Attitudes and Behavior Across the Transition to Parenthood, 46 (1):18-28.

Sabo, Don \& Merrill J. Melnick. (1996). Athletic Participation and Risk for Adolescent Pregnancy: Is there a Connection?" Paper Presented at Population Council Consultative Meeting, New York, 4 June.

Sage, G.H. (1998). Power and Ideology in American Sport (2nd Ed.), Champaign, IL: Human Kinetics, p.53. 
Sriskantharajah, J. \& Kai, J. (2007). Prompting Physical Activity among South Asian Women with Coronary Heart Disease and Diabetes: What might help? Family Practice, vol.24:1, pp.71-76.

Talbot, M. (2010). Three Decades of Progress for Physical Education, Barlin, ICSSPE, Supported by UNESCO.

Thune, I. (1997). Physical Activity and the Risk of Breast Cancer. New England Journal of Medicine, vol.18, pp.1269-1275.

Willett, W. (2003). Cancer Prevention and Early Detection. Cancer Epidemiology Biomarkers and Prevention Publication, vol.12, p.252.

World Health Organization. (2008). Country Corporation Strategy at a Glance, https://www.who.int/countries/pak/en/

Young \& White. (1995). Sport, Physical Danger and Injury: The Experiences of Elite Women Athletes. Journal of Sport and Social Issues, vol.19, pp.145-61.

Shagufta Jahangir is Ph.D Scholar in the Centre of Excellence for Women's Studies, University of Karachi.

Dr. Asma Manzoor is an Assistant Professor in the Centre of Excellence for Women's Studies, University of Karachi. 